\title{
Simulations of Fluid Nitromethane Under Extreme Conditions
}

\author{
L.E. Fried, E.J. Reed, M.R. Manaa
}

This article was submitted to American Physical Society Topical Conference on Shock Compression of Condensed Matter Portland, OR

July 20-25, 2003

\section{July 15, 2003}

U.S. Department of Energy

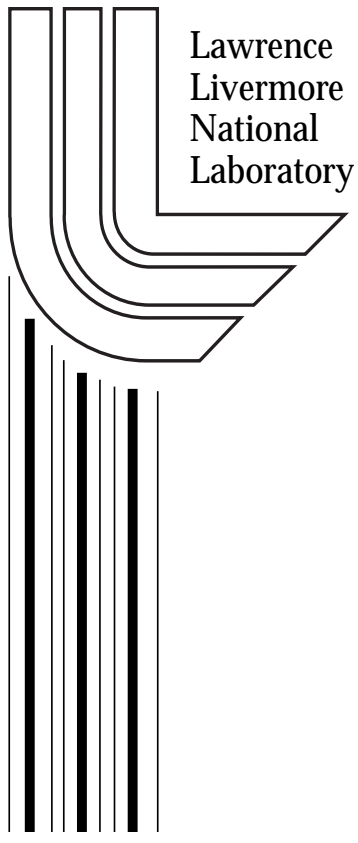




\section{DISCLAIMER}

This document was prepared as an account of work sponsored by an agency of the United States Government. Neither the United States Government nor the University of California nor any of their employees, makes any warranty, express or implied, or assumes any legal liability or responsibility for the accuracy, completeness, or usefulness of any information, apparatus, product, or process disclosed, or represents that its use would not infringe privately owned rights. Reference herein to any specific commercial product, process, or service by trade name, trademark, manufacturer, or otherwise, does not necessarily constitute or imply its endorsement, recommendation, or favoring by the United States Government or the University of California. The views and opinions of authors expressed herein do not necessarily state or reflect those of the United States Government or the University of California, and shall not be used for advertising or product endorsement purposes.

This is a preprint of a paper intended for publication in a journal or proceedings. Since changes may be made before publication, this preprint is made available with the understanding that it will not be cited or reproduced without the permission of the author.

This report has been reproduced directly from the best available copy.

Available electronically at http://www.doc.gov/bridge

Available for a processing fee to U.S. Department of Energy

And its contractors in paper from

U.S. Department of Energy

Office of Scientific and Technical Information

P.O. Box 62

Oak Ridge, TN 37831-0062

Telephone: (865) 576-8401

Facsimile: (865) 576-5728

E-mail: reports@adonis.osti.gov

Available for the sale to the public from

U.S. Department of Commerce

National Technical Information Service

5285 Port Royal Road

Springfield, VA 22161

Telephone: (800) 553-6847

Facsimile: (703) 605-6900

E-mail: orders@ntis.fedworld.gov

Online ordering: http://www.ntis.gov/ordering.htm

OR

Lawrence Livermore National Laboratory

Technical Information Department's Digital Library

http://www.llnl.gov/tid/Library.html 


\title{
SIMULATIONS OF FLUID NITROMETHANE UNDER EXTREME CONDITIONS
}

\author{
Laurence E. Fried ${ }^{1}$, Evan J. Reed ${ }^{2}$, and M. Riad Manaa ${ }^{1}$ \\ ${ }^{I}$ L-282, Chemistry and Materials Science Directorate, Lawrence Livermore National Laboratory, \\ Livermore, California 94550 \\ ${ }^{2}$ Department of Physics, Massachusetts Institute of Technology, Cambridge, Massachusetts 02139
}

\begin{abstract}
We report density functional molecular dynamics simulations to determine the early chemical events of hot $(\mathrm{T}=3000 \mathrm{~K})$ and dense $\left(1.97 \mathrm{~g} / \mathrm{cm}^{3}, \mathrm{~V} / \mathrm{V}_{0}=0.68\right)$ nitromethane $\left(\mathrm{CH}_{3} \mathrm{NO}_{2}\right)$. The first step in the decomposition process is an intermolecular proton abstraction mechanism that leads to the formation of $\mathrm{CH}_{3} \mathrm{NO}_{2} \mathrm{H}$ and the aci ion $\mathrm{H}_{2} \mathrm{CNO}_{2}{ }^{-}$, in support of evidence from static high-pressure and shock experiments. An intramolecular hydrogen transfer that transforms nitromethane into the aci acid form, $\mathrm{CH}_{2} \mathrm{NO}_{2} \mathrm{H}$, accompanies this event. This is the first confirmation of chemical reactivity with bond selectivity for an energetic material near the condition of fully reacted specimen. We also report the decomposition mechanism followed up to the formation of $\mathrm{H}_{2} \mathrm{O}$ as the first stable product.
\end{abstract}

\section{INTRODUCTION}

The reaction chemistry of energetic materials at high pressure and temperature is of considerable importance in understanding processes that these materials experience under impact and detonation conditions. Basic questions such as: (a) which bond in a given energetic molecule breaks first, and (b) what type of chemical reactions (unimolecular versus bimolecular, etc.) that dominate early in the decomposition process, are still largely unknown. The most widely studied, and archetypical example of such materials is nitromethane $\left(\mathrm{CH}_{3} \mathrm{NO}_{2}\right)$, a clear liquid with mass density $1.13 \mathrm{~g} / \mathrm{cm}^{3}$ at $298^{\circ} \mathrm{K}$. Static high-pressure experiments ${ }^{1}$ showed that the time of explosion for deuterated nitromethane is approximately ten times longer than that for protonated materials, suggesting that a proton or hydrogen atom abstraction is involved in the rate determining step. Isotope-exchange experiments, using diamond cells methods, also gave evidence ${ }^{2}$ that the aci ion concentration $\left(\mathrm{H}_{2} \mathrm{CNO}_{2}{ }^{-}\right)$increases with increased pressure. Other studies ${ }^{3}$ also suggested that reactions occur more rapidly and are pressure enhanced when small amount of bases are present, giving further support to the aci ion production. Shock wave studies of the reaction chemistry are still inconclusive and at odds: mass spectroscopic studies suggesting condensation reactions ${ }^{4}$, time-resolved Raman spectroscopy suggesting a bimolecular mechanism ${ }^{5}$, UV-visible absorption spectroscopy indicating no sign of chemical reaction ${ }^{6}$, or the production of $\mathrm{H}_{3} \mathrm{CNO}_{2}{ }^{-}$ intermediate for amine-sensitized nitromethane. ${ }^{7}$ It was noted, however, that part of the discrepancy is due to the fact that the ring-up experiments are mapping lower temperature regimes $\left(\approx 1000{ }^{\circ} \mathrm{K}\right)$ than experienced under detonation conditions $\left(\mathrm{T} \approx 2500-5000^{\circ} \mathrm{K}\right) .{ }^{4}$

In this work, we use spin-polarized, gradient corrected density-functional calculations to determine the interatomic forces, and simulate the initial decomposition steps of hot $(\mathrm{T}=3000 \mathrm{~K})$ dense $\left(1.97 \mathrm{~g} / \mathrm{cm}^{3}, \mathrm{~V} / \mathrm{V}_{0}=0.68\right)$ nitromethane at 
constant-volume and temperature conditions. The studied state is in the neighborhood of the Chapman-Jouget state, which is achieved behind a steady detonation front when the material has fully reacted. This state could be achieved through a sudden heating of nitromethane in a diamond anvil cell under constant volume conditions. Our results emphatically show that the first chemical event is a proton extraction to form $\mathrm{CH}_{3} \mathrm{NO}_{2} \mathrm{H}$, the aci ion $\mathrm{H}_{2} \mathrm{CNO}_{2}^{-}$, and the aci acid $\mathrm{H}_{2} \mathrm{CNO}_{2} \mathrm{H}$. These results are uniquely associated with the condensedphase rather than the energetically favored $\mathrm{C}-\mathrm{N}$ decomposition expected in the gas-phase.

\section{COMPUTATIONAL APPROACH}

The electronic structure calculations of the molecular forces were performed using density functional theory (DFT). ${ }^{8}$ For the exchangecorrelation potential, we used the spin-polarized generalized gradient corrected approximation of Perdew -Wang (PW91). ${ }^{9}$ Electron-ion interactions were described by Vanderbilt-type ultrasoft pseudopotentials, ${ }^{10}$ and orbitals were expanded in a plane wave basis set with kinetic energy cutoff of $340 \mathrm{eV}$. We used two k-point spacing in the Brillouin zone, each with a total number of 2921 plane waves. Minimization of the total density functional from DFT utilized the charge density mixing scheme. ${ }^{11}$ Calculations on a single unit cell were performed using the CASTEP program ${ }^{12}$, while those on larger cells employed the VASP program. ${ }^{11,13}$

Molecular dynamics simulations were carried out under constant volume and temperature using a Nose thermostat. For each MD run, random initial velocities were chosen, and a first-order Verlet extrapolation of the wave functions was used. Periodic boundary conditions, whereby a particle exiting the cell on one side is reintroduced on the opposing side with the same velocity were imposed. A dynamical time step of 0.25 fs was employed for all runs, the longest of which was 4.5 ps. Simulations were performed at a constant temperature of $3000 \mathrm{~K}$ using either one unit cell of nitromethane crystal (4 molecules, 28 atoms), a supercell with 8 molecules, and a supercell with 16 molecules. The unit cell was fully optimized at the reduced (compressed) volume, $\mathrm{V}=205.36 \AA^{3}$.

\section{RESULTS AND DISCUSSION}

The initial configuration at density $1.974 \mathrm{~g} / \mathrm{cm}^{3}$ was determined by compressing the simulation cell and performing full relaxation of all atomic coordinates. From this initial structure, molecular dynamics were performed using the Nose-Hoover thermostat at $3000 \mathrm{~K}$.

\section{$\mathbf{g}(\mathbf{R})$}
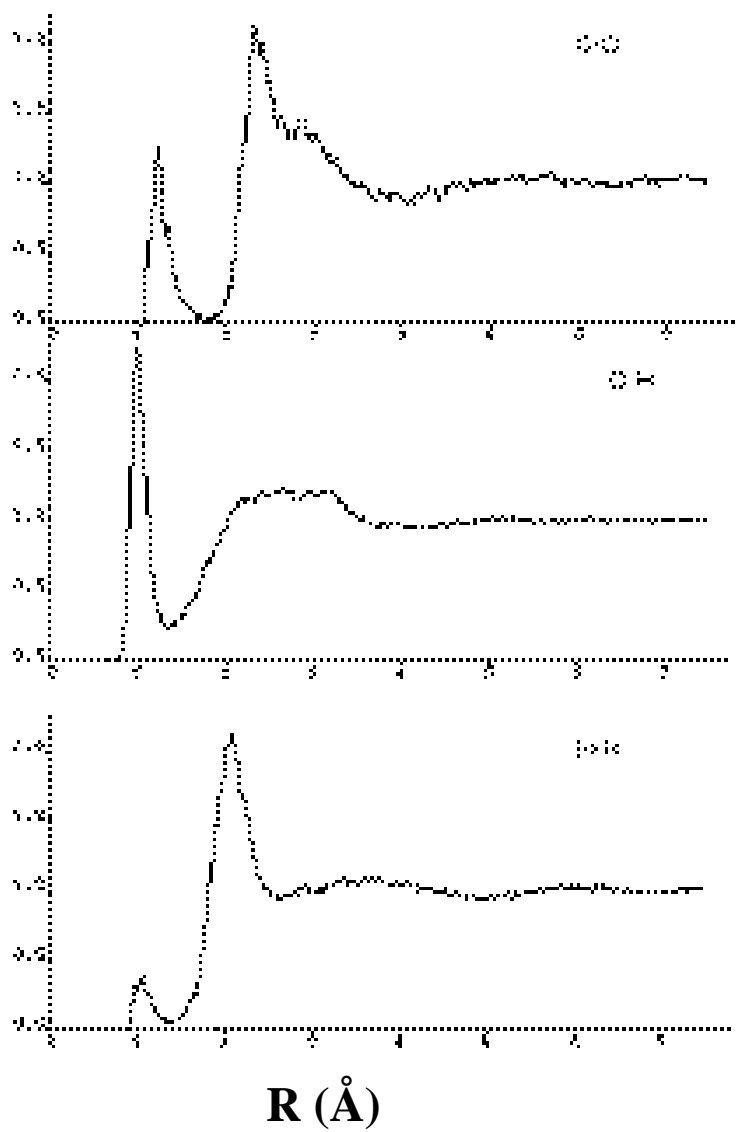
Figure 1. Calculated radial distribution functions for various intra and intermolecular bonds.

Here, we report the results obtained from the simulation using the largest supercell, consisting of four unit cells of nitromethane molecules with a repetition of $2 \times 2 \times 1$ of the unit cell and corresponding to a volume of $821.5 \AA^{3}$. The total time of this simulation was $1.16 \mathrm{ps}$.

Figure 1 shows the $\mathrm{C}-\mathrm{O}, \mathrm{O}-\mathrm{H}$, and $\mathrm{N}-\mathrm{H}$ radial distribution functions obtained over the total time of the simulation. It is evident from the distributions for the $\mathrm{C}-\mathrm{O}, \mathrm{O}-\mathrm{H}$ and $\mathrm{N}-\mathrm{H}$ that significant rearrangement of the bonds have occurred and chemistry has ensued. For C-O, the dominant population around $1.2 \AA$ is due mainly to the formation of $\mathrm{CO}_{2}$, while for $\mathrm{N}-\mathrm{H}$, the small population around $1.0 \AA$ is due to the formation of radical intermediates of $\mathrm{CH}_{2} \mathrm{NHO}$. Most interestingly is the significant population growth of $\mathrm{O}-\mathrm{H}$ at $1.0 \AA$, which encompasses the formation of $\mathrm{H}_{2} \mathrm{O}$, and in the early stages, to inter and intramolecular hydrogen bonding that leads to proton transfer.

To examine the early steps of the simulation, Figure 2 displays the variation of the $\mathrm{N}-\mathrm{O}, \mathrm{C}-\mathrm{H}$, and $\mathrm{O}-\mathrm{H}$ bond distances with time. As shown, the $\mathrm{C}-\mathrm{H}$ bond clearly undergoes a significant stretch that eventually leads to a hydrogen ejection and subsequent capture by the oxygen of a nearby nitromethane molecule, leading to the formation of $\mathrm{CH}_{3} \mathrm{NO}_{2} \mathrm{H}$ and $\mathrm{CH}_{2} \mathrm{NO}_{2}$ species.

A snapshot of the MD simulation at 59 fs where the formation of $\mathrm{CH}_{3} \mathrm{NO}_{2} \mathrm{H}$ and $\mathrm{CH}_{2} \mathrm{NO}_{2}$ takes place is shown in Figure 3. This process of proton transfer is initially facilitated by enhancement in the $\mathrm{C}-\mathrm{N}$ double bond character, and an accelerated rotation of the methyl groups $\left(\mathrm{CH}_{3}\right)$, rotations that are omnipresent even at ambient temperatures. ${ }^{14}$

The proton transfer process described above is uniquely associated with the condensed fluid phase of nitromethane. This bond specificity is remarkable, since in the gas phase the $\mathrm{C}-\mathrm{N}$ bond is the weakest in the molecule $\left(\mathrm{D}_{0}=60.1 \mathrm{kcal} / \mathrm{mol}\right)$ 15 , and is therefore expected to be the dominant dissociation channel and the initial step in the decomposition of nitromethane even at high temperature. In contrast, the $\mathrm{C}-\mathrm{H}$ bond is the strongest in the nitromethane molecule. In the condensed phase, however, vibrational energy is the highest in the $\mathrm{C}-\mathrm{H}$ mode. Due in part to a caging effect, this vibrational motion eventually leads to a proton extraction.

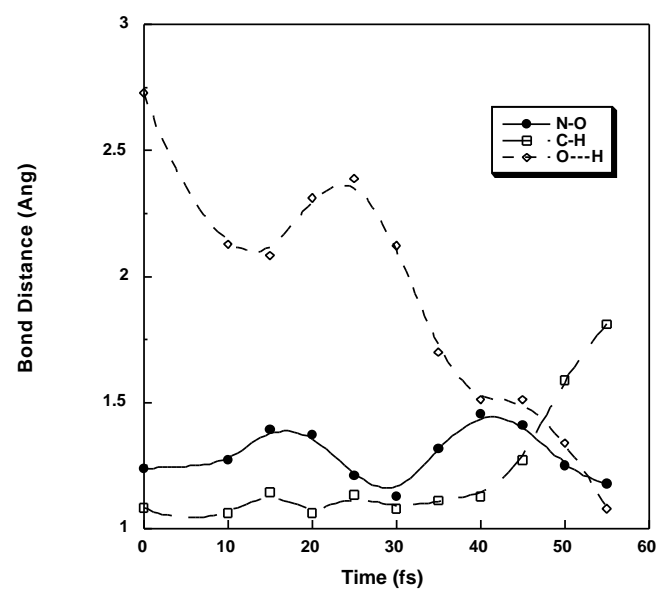

Figure 2. Time variation of intramolecular $\mathrm{C}-\mathrm{H}$ and $\mathrm{N}-\mathrm{O}$, and the intermolecular $\mathrm{O} \cdots \mathrm{H}$ bonds.

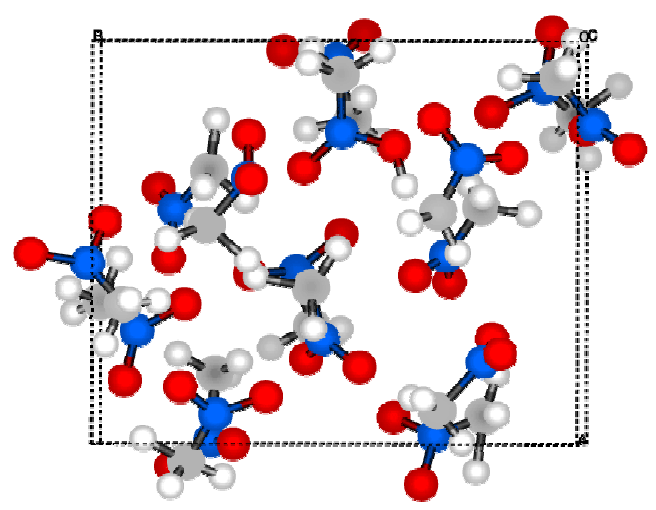

Figure 3. A snapshot of the MD simulation at $59 \mathrm{fs}$. The formation of $\mathrm{CH}_{3} \mathrm{NO}_{2} \mathrm{H}$ and $\mathrm{CH}_{2} \mathrm{NO}_{2}$ due to intermolecular hydrogen abstraction is shown.

The formation of $\mathrm{CH}_{3} \mathrm{NO}_{2} \mathrm{H}$ and $\mathrm{CH}_{2} \mathrm{NO}_{2}$ via proton extraction was observed in all three simulations of different supercell sizes. In the 
simulation on a single unit cell, the event occurs at 785 fs of the simulation time. We performed Mulliken charge analysis and listed the net charges on the atoms of the two moieties $\mathrm{CH}_{3} \mathrm{NO}_{2} \mathrm{H}$ and $\mathrm{CH}_{2} \mathrm{NO}_{2}$. We notice that the negative charge on the carbon atom of $\mathrm{CH}_{2} \mathrm{NO}_{2}$ is larger than in $\mathrm{CH}_{3} \mathrm{NO}_{2} \mathrm{H}$, while the opposite trend is exhibited for the positive charge on nitrogen. This is a manifestation of electronic charge redistribution in the region between the $\mathrm{C}$ and $\mathrm{N}$ atoms.

It is noteworthy that all three simulations (one, two and four unit cells) have yielded the same results in the formation of $\mathrm{CH}_{3} \mathrm{NO}_{2} \mathrm{H}, \mathrm{H}_{2} \mathrm{CNO}_{2}{ }^{-}$, and $\mathrm{CH}_{2} \mathrm{NO}_{2} \mathrm{H}$. Experimental concurrence for the production of the aci ion in highly pressurized and detonating nitromethane abound. Shaw et al. ${ }^{1}$ observed that the time to explosion for deuterated nitromethane is about ten times longer than that for the protonated materials, suggesting that a proton or hydrogen atom) abstraction is the ratedetermining step. Isotope-exchange experiments provided evidence that the aci ion concentration is increased upon increasing pressure ${ }^{2}$, and UV sensitization of nitromethane to detonation was shown to correlate with the aci ion presence. ${ }^{16}$ Finally, we note that a recent electronic structure study of solid nitromethane determined a significant $\mathrm{C}-\mathrm{H}$ stretch upon compression, which eventually lead to proton dissociation. ${ }^{17}$

\section{CONCLUSION}

We studied the early chemical events of hot $(\mathrm{T}=3000 \mathrm{~K})$ and dense $\left(1.97 \mathrm{~g} / \mathrm{cm}^{3}, \mathrm{~V} / \mathrm{V}_{0}=\right.$ 0.68) nitromethane using density functional molecular dynamic simulations. Three simulations on one, two , and four unit cells of crystal nitromethane have shown that the first step event in the decomposition process is an intermolecular proton abstraction mechanism that leads to the formation of $\mathrm{CH}_{3} \mathrm{NO}_{2} \mathrm{H}$ and the aci ion $\mathrm{H}_{2} \mathrm{CNO}_{2}{ }^{-}$, which lends support to experimental results from static high-pressure and shock experiments. An intramolecular hydrogen transfer that transforms nitromethane into the aci acid form, $\mathrm{CH}_{2} \mathrm{NO}_{2} \mathrm{H}$, accompanies this event. This is the first confirmation of chemical reactivity with bond selectivity for an energetic material near the condition of fully reacted specimen.

\section{ACKNOWLEDGMENTS}

This work was performed under the auspices of the U.S. Department of Energy by the Lawrence Livermore National Laboratory under contract number W-7405-Eng-48.

\section{REFERENCES}

${ }^{1}$ R. Shaw, P. S. Decarli, D. S. Ross, E. L. Lee, and H. D. Stromberg, Combust. Flame 35, 237 (1979); R. Shaw, P. S. Decarli, D. S. Ross, E. L. Lee, and H. D. Stromberg, Combust. Flame 50, 123 (1983).

${ }^{2}$ R. Engelke, D. Schiferl, C. B. Storm, and W. L. Earl, J. Phys. Chem. 92, 6815 (1988).

${ }^{3}$ J. W. Brasch, Journal of Physical Chemistry 84, 2084 (1980); D. L. Naud and K. R. Brower, High-Pressure Research 11, 65 (1992).

${ }^{4}$ N. C. Blais, R. Engelke, and S. A. Sheffield, Journal of Physical Chemistry A 101, 8285 (1997).

${ }^{5}$ J. M. Winey and Y. M. Gupta, Journal of Physical Chemistry B 101, 10733 (1997).

${ }^{6}$ J. M. Winey and Y. M. Gupta, Journal of Physicall Chemistry A 101, 9333 (1997).

${ }^{7}$ Y. A. Gruzdkov and Y. M. Gupta, Journal of Physical Chemistry A 102, 2322 (1998).

${ }^{8}$ P. Hohenberg and W. Kohn, Phys. Rev. 136, B864 (1964).

${ }^{9}$ J. P. Perdew and Y. Wang, Phys. Rev. B 46, 6671 (1992).

${ }^{10}$ D. Vanderbilt, Phys. Rev. B 41, 7892 (1990).

${ }^{11}$ G. Kresse and J. Furthmuller, Phys. Rev. B 54, 11169 (1996).

${ }^{12}$ A. Inc., Cerius 2 Modling Environment (Accelrys Inc., San Diego, 1999).

13 G. Kresse and J. Hafner, Phys. Rev. B 47, RC558 (1993).

14 M. E. Tuckerman and M. L. Klein, Chem. Phys. Lett. 283, 147 (1998); D. C. Sorescu, B. M. Rice, and D. L. Thompson, J. Phys. Chem. B 104, 8406 (2001).

15 J. B. Pedley, R. D. Naylor, and S. P. Kirby, Thermochemical Data of Organic Compounds, 2nd ed. ed. (Chapman, New York, 1986).

16 R. Engelke, W. L. Earl, and C. M. Rohlfing, J. Phys. Chem. 90, 545 (1986).

17 D. Margetis, E. Kaxiras, M. Elstner, T. Frauenheim, and M. R. Manaa, J. Chem. Phys. 117, 788 (2002). 